\title{
Severe hepatitis with autoimmune features following a HHV-6: a
} case report Pierfrancesco Grima*, Roberto Chiavaroli, Paola Calabrese, Paolo Tundo and Piero Grima

Address: Division of Infectious Disease, "Santa Caterina Novella" Hospital, Galatina, Italy

Email: Pierfrancesco Grima* - pierfrancescogrima@yahoo.it; Roberto Chiavaroli - robertokia@yahoo.it;

Paola Calabrese - calabrese_paola@tiscali.it; Paolo Tundo - tundop@libero.it; Piero Grima - pierogrima@libero.it

* Corresponding author

Published: 18 August 2008

Cases Journal 2008, I:II0 doi:10.1186/1757-1626-1-110

This article is available from: http://www.casesjournal.com/content/I/I/II0

(C) 2008 Grima et al; licensee BioMed Central Ltd.

This is an Open Access article distributed under the terms of the Creative Commons Attribution License (http://creativecommons.org/licenses/by/2.0), which permits unrestricted use, distribution, and reproduction in any medium, provided the original work is properly cited.
Received: 21 May 2008

Accepted: 18 August 2008

\begin{abstract}
HHV-6 has been identified as the aetiologic agent of exanthem subitum in infants and an acute febrile illness in young children. HHV-6 probably remains latent in the body after the primary infection and it reactivates upon host immunosuppression in a manner similar to other human herpes viruses. Primary HHV-6 infection in adults is very rare and it is not clear whether disease manifestations are similar to those observed in children.

We report the case of acute hepatitis in a 18-year-old immunocompetent woman presenting with sever jaundice and liver dysfunction. Serum immunoglobulin levels were elevated ( $3.8 \mathrm{gr} / \mathrm{dl})$ with a titre of anti nucleus antibody of 1:640. Serological data demonstrated the presence of IgM antibodies against human herpesvirus- 6 in the serum and of viral DNA on liver biopsy by real time quantitative polymerase chain reaction, with a viral load of 280 genomes $/ 10^{6}$ of cellular genomes. No other etiologic agents were found to induce hepatitis and the patient was diagnosed as having HHV-6 triggered autoimmune acute hepatitis.
\end{abstract}

\section{Introduction}

Human herpesvirus 6 (HHV-6) was first isolated from patients with the acquired immunodeficiency syndrome or lymphoproliferative diseases and was named human B lymphotropic virus [1]. HHV-6 has been identified as the etiologic agent of exanthema subitum in infants [2] and an acute febrile illness in young children [3]. Most people are seropositive for HHV- 6 by the age of three years [4]. HHV-6 also produces latent or chronic infections [5] and is occasionally reactivated in immunocompromised hosts $[1,6]$. Furthermore, HHV-6 has been implicated in several diseases in immunocompetent adults, including Kikuchi's lymphadenitis [7] and an infectious mononucleosis-like syndrome that is negative for Epstein-Barr virus and cytomegalovirus [8]. We describe the immunopathological and clinical features of a severe acute hepatitis in a 18year-old woman that was probably caused by a primary infection with HHV-6.

\section{Case presentation}

A 18-year-old woman was admitted to S.Caterina Novella Hospital on October 10, 2006, with a fifteenday history of flu-like syndrome. She had been healthy and had a history of self-limiting viral infections including measles and rubella in childhood. Physical examination revealed left cervical lymphadenopathy, splenomegaly and sever jaundice. Abnormal laboratory findings included a white blood cell count of $4.9 \times 10^{9} / \mathrm{L}$ ( $3 \%$ atypical lymphocytes) 
with large granular cells and anisocytosy in peripheral smear.

Liver dysfunction was seen, with an increase in the levels of aspartate aminotransferase (1515 IU/l), alanine aminotransferase (1658 IU/l), lactate dehydrogenase (1080 $\mathrm{IU} / \mathrm{l})$ and total bilirubin $(18.6 \mathrm{mg} / \mathrm{dl})$. Prothrombin time was $28 \%$. Serum immunoglobulin levels were elevated $(3.8 \mathrm{gr} / \mathrm{dl})$ with a titre of anti nucleus antibody (ANA) of 1:640. No antibodies against human immunodeficiency virus (HIV), hepatitis C virus (HCV), Hepatitis B virus (HBV), Cytomegalovirus (CMV), Epstein Barr Virus (EBV) were detected. However anti-HHV-6 antibody (IgG and IgM) were detected with IgM index of 3.2 (cut off for positive control > 1.1). A diagnosis of hepatic failure was made, and liver biopsy was performed during the acute stage. Histologic examination showed moderate infiltration of atypical lymphoid cells and diffuse focal vacuolar degeneration of hepatocytes. The infiltrating lymphocytes were positive for $\mathrm{CD} 3, \mathrm{CD} 4$, and $\mathrm{CD} 8$, but negative for CD20. The presence of HHV-6 DNA was shown in liver tissue by polymerase chain reaction (PCR) with a viral load of 280 genomes $/ 10^{6}$ of cellular genomes, suggesting active viral replication in the hepatocytes. Methylprednisolone was administered for three weeks beginning on the seventh day of hospitalization with dosage of $25 \mathrm{mg}$ every twelve hours. The jaundice, lymphadenopathy and splenomegaly gradually disappeared and patient was sent home on the 35th hospital day with a normal hepatic function and no clinical sequelae. At 2 months HHV6 IgM antibodies decreased and disappeared after 3 months.

\section{Discussion}

Our data indicate that HHV-6 was the cause of our patient's acute illness. Serologic studies excluded the possibility of active infection by HCV, HBV or other human herpesviruses such CMV and EBV. The presence of HHV-6 IgM antibodies shortly after the onset of liver disease and positive ANA titres suggest that HHV6 or an autoimmune disease may also be involved in the pathogenesis. HHV-6 is a CD4 lymphotropic virus isolated from T-cells cultures derived from the blood of subjects HIV+ [1]. Infection by HHV6 is rapidly controlled by the host immune response, and the virus established a state of latency. Primary infection occurs mostly in early childhood and only rarely in adults, in whom the prevalence of anti-HHVG IgG is more than $90 \%$ [3]. Symptomatic infection is characterized by fever, skin rash (exanthema subitum), sometimes associated with mild respiratory illness, leukopenia and atypical lymphocytosis $[3,10]$. Recovery is usually rapid and benign, although a more severe course with meningitis, encephalitis, myocarditis or hepatitis, variable from mild hepatitis to fulminant liver failure, has been described [3]. HHV6 has also been associated with interstitial pneumonia and encephalitis in immunocompromised patients.
[11] We assume that HHV-6 caused the initial clinical manifestations but an humoral virus-triggered autoimmune reaction, indicated by the positive ANA titre, responding to immunosuppression induced hepatic damage. Manifestations of autoimmune hepatitis have been described repeatedly after infection with hepatitis A, B and $\mathrm{C}$ as well as with herpes viruses, namely HSV1, EBV and HHV6 [12,13].

\section{Conclusion}

Autoantibodies may be triggered by a virus specific mechanism to evade immune responses called 'molecular mimicry', when domains on viral proteins closely resembling human self-epitopes are generated $[14,15]$. Thus, we believe that in addition to causing exanthem subitum in infants and a febrile illness in children, HHV-6 type B can cause an acute and potentially fulminant hepatitis in adults with an autoimmune pathogenetic mechanism.

\section{Competing interests}

The authors declare that they have no competing interests.

\section{Authors' contributions}

PGjr acquisited data and made analysis and interpretation of data, PC assessed ultrasonographic examination, RC assessed liver biopsy, PG analized tissue molecular test and helped to draft the manuscript. All authors read and approved the final manuscript. Informed written consent was received from the patient for publication of the manuscript.

\section{References}

I. Salahuddin SZ, Ablashi DV, Markham PD, Josephs SF, Sturzenegger S, Kaplan M, Halligan G, Biberfeld P, Wong-Staal F, Kramarsky B, Gallo $R C$ : Isolation of a new virus, $H B L V$ in patients with lymphoproliferative disorders. Science 1986, 234:596-60I.

2. Yamanishi K, Okuno T, Shiraki K, Takahashi M, Kondo T, Asano Y, Kurata T: Identification of human herpesvirus-6 as a causal agent for exanthem subitum. Lancet 1988, I:1065-1067.

3. Pruksananonda P, Hall CB, Insel RA, Mclntyre K, Pellett PE, Long CE, Schnabel KC, Pincus PH, Stamey FR, Dambaugh TR, Stewart JA: Primary human herpesvirus 6 infection in young children. $N$ Engl J Med 1992, 326: |445-|450.

4. Briggs M, Fox J, Tedder RS: Age prevalence of antibody to human herpesvirus 6. Lancet 1988, I: 1058-1059.

5. Kondo K, Kondo T, Okuno T, Takahashi M, Yamanishi K: Latent human herpesvirus 6 infection of human monocytes/macrophages. J Gen Virol I99I, 72:|40।-|408.

6. Yoshikawa T, Suga S, Asano Y, Nakashima T, Yazaki T, Sobue R, Hirano M, Fukuda M, Kojima S, Matsuyama T: Human herpesvirus6 infection in bone marrow transplantation. Blood 1991, 78: $|38|-1384$.

7. Eizuru Y, Minematsu T, Minamishima Y, Kikuchi M, Yamanishi K, Takahashi M, Kurata T: Human herpesvirus 6 in lymph nodes. Lancet 1989, I:40-40.

8. Niederman JC, Liu C-R, Kaplan MH, Brown NA: Clinical and serological features of human herpesvirus- 6 infection in three adults. Lancet 1988, 2:817-819.

9. Ishikawa K, Hasegawa K, Naritomi T, Kanai N, Ogawa M, Kato $Y$, Kobayashi M, Torii N, Hayashi N: Prevalence of herpesviridae and hepatitis virus sequences in the livers of patients with fulminant hepatitis of unknown etiology in Japan. J Gastroenterol 2002, 37:523-530. 
10. Kuntzen T, Friedrichs N, Fischer HP, Eis-Hübinger AM, Sauerbruch T, Spengler U: Postinfantile giant cell hepatitis with autoimmune features following a human herpesvirus 6 -induced adverse drug reaction. Eur J Gastroenterol Hepatol I 7: | | 3 I- | | 43.

II. Ihira M, Yoshikawa T, Ishii J, Nomura M, Hishida H, Ohashi M, Enomoto Y, Suga S, lida K, Saito Y, Nishiyama Y, Asano Y: Serological examination of human herpesvirus 6 and 7 in patients with coronary artery disease. J Med Virol 2002, 67:534-537.

12. Sobue R, Miyazaki H, Okamoto M, Hirano M, Yoshikawa T, Suga S, Asano $Y$ : Fulminant hepatitis in primary human herpesvirus6 infection. N Engl J Med I99I, 324:1290.

13. Schmitt K, Deutsch J, Tulzer G, Meindi R, Aberle S: Autoimmune hepatitis and adrenal insufficiency in an infant with human herpesvirus-6 infection. Lancet 1996, 348:966.

14. Huppertz HI, Treichel U, Gassel AM, Jeschke R, Meyer zum Buschenfelde $\mathrm{KH}$ : Autoimmune hepatitis following hepatitis $\mathbf{A}$ virus infection. J Hepatol 1995, 23:204-208.

15. Kammer AR, Burg SH van der, Grabscheid B, Hunziker IP, Kwappenberg KM, Reichen J, Melief CJ, Cerny A: Molecular mimicry of human cytochrome $\mathbf{P 4 5 0}$ by hepatitis $C$ virus at the level of cytotoxic T cell recognition. J Exp Med 1999, 190:169-176.

Publish with Bio Med Central and every scientist can read your work free of charge

"BioMed Central will be the most significant development for disseminating the results of biomedical research in our lifetime. "

Sir Paul Nurse, Cancer Research UK

Your research papers will be:

- available free of charge to the entire biomedical community

- peer reviewed and published immediately upon acceptance

- cited in PubMed and archived on PubMed Central

- yours - you keep the copyright 